\title{
Evaluation of Relationship Between Prevalence of Palmaris Longus Muscle and Handedness in Turkish Population
}

\author{
Evaluación de la Relación entre la Prevalencia del \\ Músculo Palmar Largo en la Población Turca \\ Keziban Karacan'; Melike Akcaalan1 \& Hüseyin Baylan ${ }^{1}$
}

\begin{abstract}
KARACAN, K.; AKCAALAN. M. \& BAYLAN, H. Evaluation of relationship between prevalence of palmaris longus muscle and handedness in Turkish population. Int. J. Morphol., 35(3):1026-1030, 2017.

SUMMARY: Palmaris longus (PL) is a fusiform muscle with a short belly and a long tendon that crosses superficially over flexor retinaculum. It flexes wrist and tenses palmar aponeurosis. The absence of PL prevalence varies from $0.6 \%$ to $63.91 \%$ in the literature. The existence of PL on the right hand is more common compared to the left hand. Thus, we aimed to determine the prevalence of PL in the Turkish population and the relation of PL absence with sex and handedness in this study. We evaluated 1050 students of Sakarya University between ages 18-28 who participated in the study (525 males, 525 females). After completing a questionnaire including handedness, the volunteers were examined on both hands using some standard tests to find out PL absences. Pearson chisquare and Fischer's exact tests were used for statistics in SPSS 22 software. It was determined that 937 subjects were right-handed (89.2 $\%), 70$ subjects were left-handed $(6.6 \%)$ and 43 subjects were ambidextrous (4.1\%). The presence of bilateral PL was found in 653 subjects, while the absence of bilateral PL was defined in 186 subjects. The absence of PL on right and left hand was detected respectively on $108(10.3 \%)$ and $103(9.8 \%)$ subjects. Left-handedness was more common in males (7.2\%) than females (6\%). PL was absent in 397 $(37.8 \%)$ subjects unilaterally and bilaterally. The study showed that our population has similar prevalence of PL absence with literature. Moreover, there was no correlation statistically between the absence of PL and sex or handedness.
\end{abstract}

KEY WORDS: Variation of muscle; Agenesis; Ambidextrous; Sex.

\section{INTRODUCTION}

Palmaris longus (PL) is a slender and fusiform muscle which is unusual with its short belly and long tendon. It is a superficial flexor muscle of forearm that lies medial to flexor carpi radialis. It originates from medial epicondle by the common tendon of humerus and fascia antebrachii and inserts into aponeurosis palmaris and the distal part of retinaculum flexorum. It passes as a tendon below part of antebrachii and crosses the retinaculum flexorum superficially (Fig. 1). It is innervated by the median nerve and used as an indicator to find median nerve in surgeries (Standring, 2005).

Its main function is to flex the wrist and tense the palmar aponeurosis, but PL is suggested to have no effect on gripping movement (Köse et al., 2012). So, surgeons often use it as a donor tendon for transfer or transplant. It is functionally negligible and often used as a graft tendon in a variety of surgical procedures such as correction of ptosis, management of facial paralysis and lip augmentation (Kapoor et al., 2008).
$\mathrm{PL}$ is one of the most variable muscles in human body. Some of the variations include classical, double, reversed, central, bifid, multiple headed; and even the muscle may be completely absent (agenesis) either unilaterally or bilaterally (Ahn et al., 2000). The absence of PL varies in prevalence from $0.6 \%$ to $63.91 \%$ in literature (Ceyhan \& Mavt, 1997; Ahn et al.). But the knowledge of the relationship between handedness and absence of PL is limited in the literature.

As it is commonly known, most people (about 70-95 $\%)$ are right-handed, a minority (about 5-30 \%) are lefthanded, and an indeterminate number of people are probably best described as ambidextrous (Holder, 2001).

Therefore, the aim of this study was to determine the prevalence of presence or absence of PL and its relation with sex and handedness in Turkish population.

${ }^{1}$ Departmant of Anatomy, Faculty of Medicine, University of Sakarya, 54290, Sakarya, Turkey. 


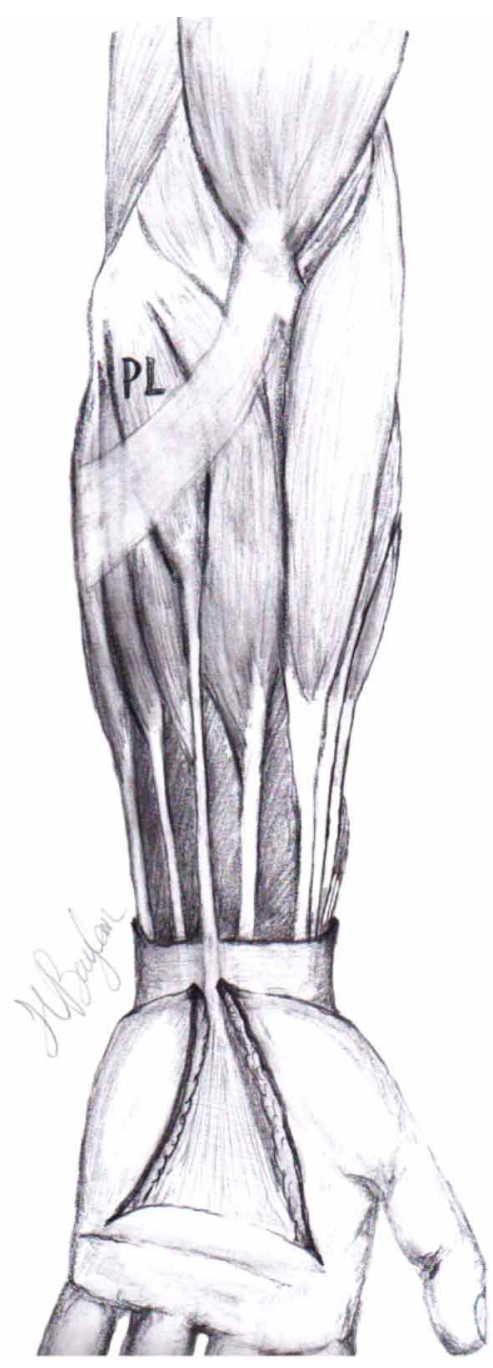

Fig. 1 The illustration of palmaris longus muscle.

\section{MATERIAL AND METHOD}

In this study we included 1050 (525 males, 525 females) students of Sakarya University between ages $18-28$ (mean age 20.16). Students were randomly selected. Ethics committee report (71522473/050.01.04/107) and inter-agency necessary permissions were received before the study. Subjects who had any history of injury, disease, surgery, scar, abnormality in the upper limbs were excluded from the study. Each volunteer completed a questionnaire including age, sex, and handedness (Geschwind \& Behan, 1982).

Subjects were examined by using tests in terms of presence or absence of PL on both hands. A single examiner checked all subjects. The tests are explained in the following:

Schaeffer's test (Standard test): the subject is asked to oppose the thumb to the little finger and then flex the wrist (Schaeffer, 1909) (Fig. 2).

Thompson's test: the subject is asked to make a fist, then flex the wrist and finally the thumb is opposed and flexed over the fingers (Thompson et al., 1921) (Fig. 3).

Mishra's 1st test: The metacarpophalangeal joints of all fingers are passively hyperextended by the examiner and the subject is asked to actively flex the wrist (Mishra, 2001) (Fig. 4).

Categorical variables were compared by Chi-Square test. These variables were presented as a count and percentage. A p-value $<0.05$ was considered as significant. Analyses were performed by the use of commercial software (IBM SPSS Statistics, Version 22.0. Armonk, NY: IBM Corp.)

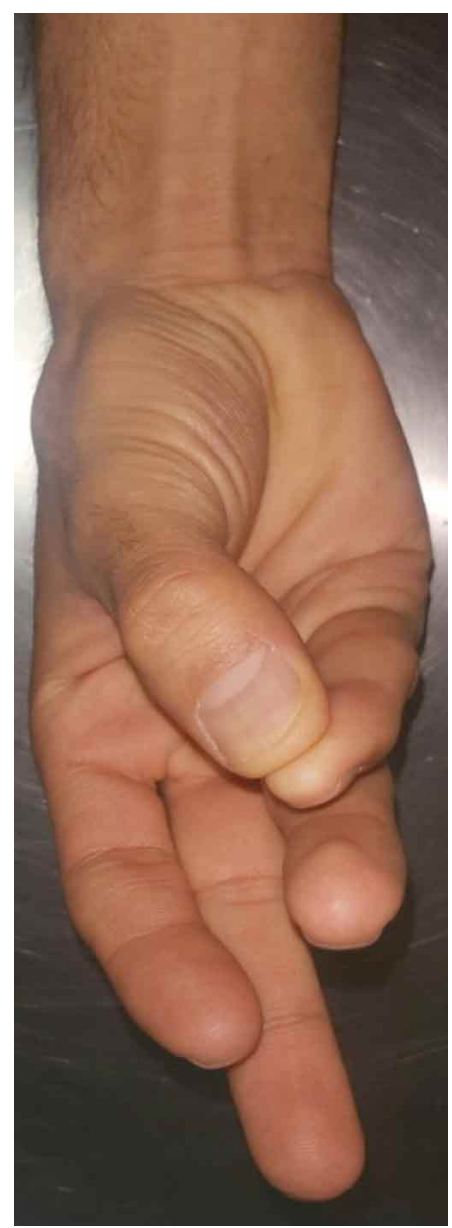

Fig. 2. Schaeffer's test (Standard test).

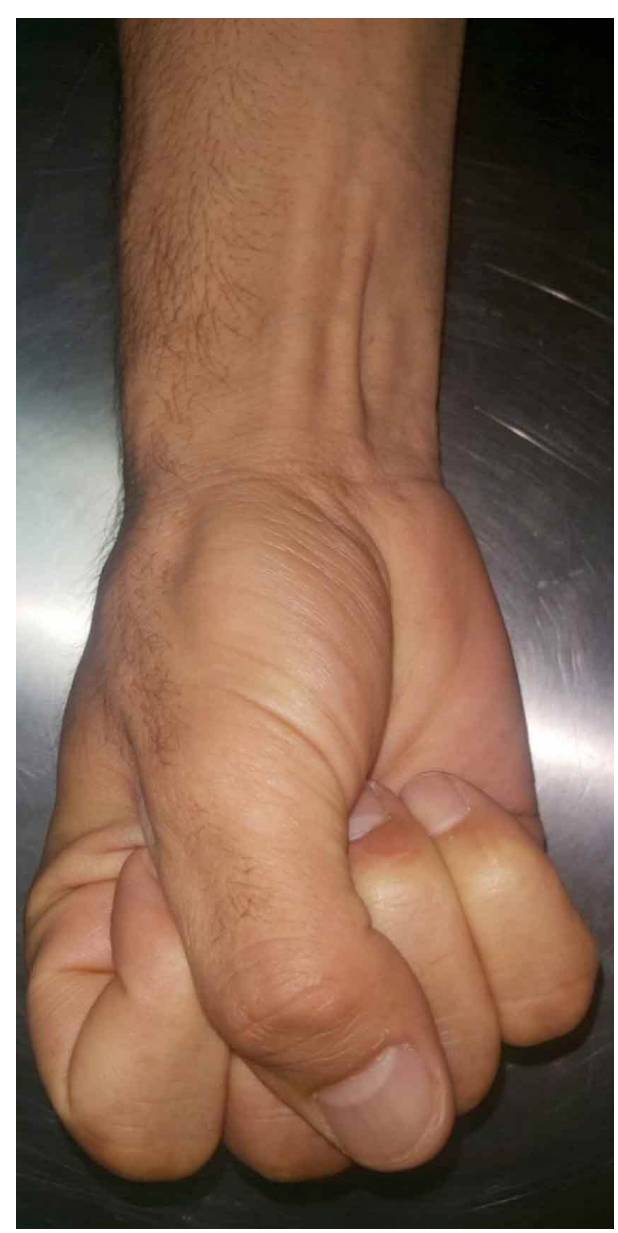

Fig. 3. Thompson's test. 


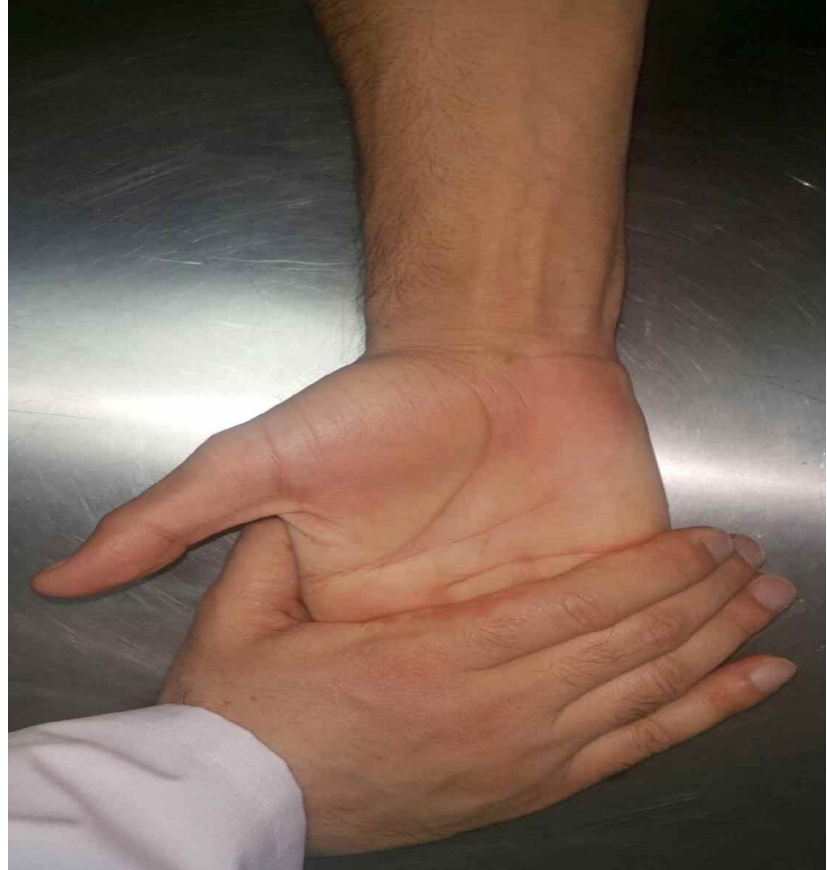

Fig. 4 Mishra's 1st test.

\section{RESULTS}

The bilateral presence of PL was recorded in 653 subjects $(62.2 \%)$, while bilateral absence was detected in 186 subjects $(17.7 \%)$ of 1050 subjects.

Right absence of PL was determined in 57 females $(52.8 \%)$ and 51 males $(47.2 \%)$ of total 108 subjects $(10.3$ $\%$ ) while left absence of PL was determined in 50 females $(48.5 \%)$ and 53 males $(51.5 \%)$. Therefore, these findings were statistically insignificant $(\mathrm{p}=0.336, \mathrm{p}>0.05)$.
Bilateral absence of PL in females $(55.4 \%)$ was higher than males $(44.6 \%)$. Although right absence was higher in females than males, left absence was vice versa (Table I).

Out of the 1050 subjects, 937 subjects $(89.2 \%)$ were right-handed, 70 subjects $(6.6 \%)$ were left-handed and 43 subjects $(4.1 \%)$ were ambidextrous. While left-handedness was more common in males $(7.2 \%)$ than females $(6.1 \%)$, right-handedness was more common in females $(90.1 \%)$ than males $(88.4 \%)$. But it was statistically insignificant $(\mathrm{p}=0.66, \mathrm{p}>0.05)$.

PL was overall absent (unilateral and bilateral) in 397 (37.8\%) subjects. Overall absence was higher in females $(40 \%)$ than males $(35.6 \%)$ (Table I).

With respect to the relationship between handedness and PL absence, it was found that right absence of PL ratio $(2.8 \%)$ was high in the left-handed subjects, and left absence of PL ratio $(92.2 \%)$ were high in the right-handed subjects. The bilateral presence of PL is high in the ambidextrous subjects, therefore these findings were statistically significant $(\mathrm{p}=0.04, \mathrm{p}<0.05)$ (Table II).

\section{DISCUSSION}

PL is found only in mammals among vertebrates. Especially, it is always present in the orangutan due to using quite often their forelimbs for ambulation. But it can be absent in higher apes such as chimpanzees and gorillas (Eric et al., 2010). PL is highlighted that it is a phylogenetically degenerate metacarpophalangeal joint flexor in literature (Köse et al., 2009).

Table I. The relationship between handedness, sex, and palmar longus muscle.

\begin{tabular}{|c|c|c|c|c|c|c|}
\hline PL & & $\begin{array}{c}\text { Absent } \\
\text { bilaterally }\end{array}$ & $\begin{array}{c}\text { Absent in left } \\
\text { hand }\end{array}$ & $\begin{array}{c}\text { Present } \\
\text { bilaterally }\end{array}$ & $\begin{array}{l}\text { Absent in right } \\
\text { hand }\end{array}$ & $\mathrm{p}$ \\
\hline \multirow{3}{*}{ S ex } & Female & $103(55.4 \%)$ & $50(48.5)$ & $315(48.2)$ & $57(52.8)$ & \multirow{3}{*}{0.336} \\
\hline & Male & $83(44.6 \%)$ & $53(51.5)$ & $338(51.8)$ & $51(47.2)$ & \\
\hline & Left-handedness & $18(9.7)$ & $8(7.8)$ & $41(6.3)$ & $3(2.8)$ & \\
\hline \multirow[t]{2}{*}{ Hand Preference } & Right-handedness & $163(87.6)$ & $95(92.2)$ & $578(88.5)$ & $101(93.5)$ & \multirow[t]{2}{*}{$* 0.045$} \\
\hline & Ambidextrous & $5(2.7)$ & $0(0)$ & $34(5.2)$ & $4(3.7)$ & \\
\hline
\end{tabular}

Table II. The relationship between handedness and sex.

\begin{tabular}{lllll}
\hline & Right-handedness & Left-handedness & Ambidextrous & $\mathrm{p}$ \\
\hline Female & $473(90.1 \%)$ & $32(6.1 \%)$ & $20(3.8 \%)$ & 0.66 \\
Male & $464(84.4)$ & $38(7.2 \%)$ & $23(4.4 \%)$ & \\
\hline
\end{tabular}


The functional effect of the presence of PL is still controversial in humans. Some researchers (Sebastin et al., 2005a) suggest that PL has no big effect for grip or pinch strength in hands, while some others (Gangata et al., 2010) suggest that PL strengthens the thumb gripping power. But it is significant when a donor tendon for transfer or transplant is needed without causing any functional decrease for the patients (Kleinert et al., 1991).

PL is a variational muscle and the most common variation is the agenesis of the entire muscle. The prevalence of PL absence can vary in different populations.

While the overall absence of PL was $36.8 \%$ in Bahraini population (Sater et al., 2010), it was $1.5 \%$ in Zimbabwean population and the latter value was the lowest rate (Gangata, 2009). Sebastin et al. (2005b) pointed out that overall absence of PL was as $4.6 \%$ in the Chinese population, and Sankar et al. (2011) claimed this ratio as 28 $\%$ in Indian population. Eric et al. found overall absences as $37.5 \%$ in males and $35.5 \%$ in females. Contrarily, Raouf $e t$ al. (2013) and our results suggest that overall absence is higher in females.

The right absence of PL was $2 \%$ in Amazon Indians (Machado \& Di Dio, 1967), although this ratio was low, it was close to the results of Mbaka \& Ejiwunmi (2009) (2.5\%) and Kapoor et al. (3\%) studies. The right absence was found as $11.9 \%$ and $10.2 \%$ in the Iranian and Egyptian populations, respectively (Abdolahzadeh Lahiji et al., 2013; Raouf et al.).

The finding of our study was almost same with the Iranian population (Thompson et al.). Eric et al. suggested that right absence of PL is higher in males but Raouf et al. and our study showed that it is lower in males.

The left absence of PL was $2 \%$ in Amazon Indians same as right absence (Machado \& Di Dio). The closest result to this study was performed by Mbaka \& Ejiwunmi, which is $3.2 \%$. The highest ratio of the left absence in literature was determined as $13 \%$ by Eric et al. Raouf et al. emphasized left absence of PL as $7.8 \%$, and this ratio was in accordant with our result $(9.8 \%)$. Eric et al. and Raouf $e t$ al. determined the left absence of PL as higher in females than males in contrast to our findings (Kleinert et al.).

The bilateral absence of PL was $1 \%$ in Nigerian population (Mbaka \& Ejiwunmi), which was the lowest result in literature. However, Ceyhan \& Mavt emphasized this absence prevalence as $43 \%$ (Holder). This ratio is so high that there might be some mistakes about detecting the tendon of PL. Because the tendon of PL can be confused by the examiners with the tendon of flexor carpi radialis muscle.
The bilateral absence of PL was $17.7 \%$ in our study.

While Raouf et al., identified that bilateral absence of PL is higher in males than females. Eric et al. and our study suggest that it is lower in males than females.

The prevalence of PL can vary in different studies which were performed even in the same population. For example, while overall absence prevalence of overall absence of PL was found as $37.8 \%$ in our study, it has been reported between $15.9 \%$ and $63.9 \%$ in other studies in the Turkish population. While the right absence of PL was $10.3 \%$ in our study, Köse et al., reported as $4.5 \%$ in Turkish population.

The knowledge showing the relationship between handedness and the presence of PL is quite limited in the literature. Also, Abledu \& Offei (2014) emphasized that there was no relationship between the absence of PL and handedness in their study concerning the relationship between dominant hand and presence of PL in Gana. Likewise, Sharma et al. (2012) pointed out in their study that there was no relationship between handedness and absence of PL in India. However, we found that right absence of PL was high in left-handed individuals, left absence of PL was high in right-handed individuals and the bilateral presence of PL was high in ambidextrous individuals. It was statistically significant in our study $(\mathrm{p}=0.04, \mathrm{p}<0.05)$.

The absence of PL can differ in terms of the populations and the measurement techniques done by the examiners. Indeed, it is quite difficult to examine physically deep structures like PL. Some mistakes may be caused by the examiners during determining the absence or presence of muscle. About this subject, certain affirmation can be performed by the use of MR or USG. However, these methods are quite expensive.

As a conclusion, our study puts forth the possibility of that there can be a relationship between the absence of PL and hand preference. We believe that this study can be a source for other researchers and also needs to be supported by other studies.

KARACAN, K.; AKCAALAN. M. \& BAYLAN, H. Evaluación entre la prevalencia del músculo palmar largo en la población turca.. Int. J. Morphol., 35(3):1026-1030, 2017.

RESUMEN: El músculo palmar largo (PL) es un músculo fusiforme, con un vientre corto y un tendón largo que cruza superficialmente el retináculo flexor. Flexiona la muñeca y tensiona la aponeurosis palmar. La ausencia de prevalencia de PL varía de 0,6 $\%$ a 63,91 \% en la literatura. La presencia de PL en la mano derecha es más común en comparación con la mano izquierda. Por lo 
tanto, nuestro objetivo en este estudio fue determinar la prevalencia de PL en la población turca y la relación de ausencia de PL con el sexo y la mano. Evaluamos a 1050 estudiantes de la Universidad de Sakarya entre 18-28 años de edad que participaron en el estudio (525 varones, 525 mujeres). Después de completar un cuestionario se examinaron ambas manos de los participantes usando algunas pruebas estándar para determinar la ausencia de PL. Se aplicaron las pruebas de Chi-cuadrado, Pearson y Fischer mediante el software SPSS 22. Se determinó que 937 sujetos eran diestros $(89,2 \%), 70$ sujetos zurdos $(6,6 \%)$ y 43 sujetos ambidiestros $(4,1$ $\%)$. La presencia de PL bilateral se encontró en 653 sujetos, mientras que la ausencia de PL bilateral se definió en 186 sujetos. La ausencia de PL en los antebrazos derecho e izquierdo fue detectada en 108 casos $(10,3 \%)$ y 103 casos $(9,8 \%)$, respectivamente. La prevalencia de zurdos fue más común en los hombres $(7,2 \%)$ que en las mujeres (6\%). El PL estuvo ausente en 397 (37,8\%) sujetos unilateralmente y bilateralmente. El estudio mostró que nuestra población tiene similar prevalencia de ausencia de PL con respecto a lo hallado en la literatura. Por otra parte, no hubo correlación estadística entre la ausencia de PL y el sexo o la mano.

PALABRAS CLAVE: Variación muscular; Agenesia; Ambidextro; Sexo.

\section{REFERENCES}

Abdolahzadeh Lahiji, F.; Ashoori, K. \& Dahmardehei, M. Prevalence of palmaris longus agenesis in a hospital in Iran. Arch. Iran Med., 16(3):187-8, 2013.

Abledu, J. K. \& Offei, E. B. Prevalence of agenesis of palmaris longus muscle and its association with gender, body side, handedness and other anomalies of the forearm in a student population in Ghana. Rawal Med. J., 39(2):203-7, 2014

Ahn, D. S; Yoon, E. S.; Koo, S. H. \& Park, S. H. A prospective study of the anatomic variations of the median nerve in the carpal tunnel in Asians. Ann. Plast. Surg., 44(3):282-7, 2000.

Ceyhan, O. \& Mavt, A. Distribution of agenesis of palmaris longus muscle in 12 to 18 years old age groups. Indian J. Med. Sci., 51(5):156-60, 1997.

Eric, M.; Krivokuca, D.; Savovic, S.; Leksan, I. \& Vucinic, N. Prevalence of the palmaris longus through clinical evaluation. Surg. Radiol. Anat., 32(4):357-61, 2010.

Gangata, $H$. The clinical surface anatomy anomalies of the palmaris longus muscle in the Black African population of Zimbabwe and a proposed new testing technique. Clin. Anat., 22(2):230-5, 2009.

Gangata, H.; Ndou, R. \& Louw, G. The contribution of the palmaris longus muscle to the strength of thumb abduction. Clin. Anat., 23(4):431-6, 2010.

Geschwind, N. \& Behan, P. Left-handedness: association with immune disease, migraine, and developmental learning disorder. Proc. Natl. Acad. Sci. U. S. A., 79(16):5097-100, 1982.

Holder, M. Why are more people right-handed? Scientific American, 2001. Available from: https://www.scientificamerican.com/article/why-aremore-people-right/

Kapoor, S. K.; Tiwari, A.; Kumar, A.; Bhatia, R.; Tantuway, V. \& Kapoor, S. Clinical relevance of palmaris longus agenesis: common anatomical aberration. Anat. Sci. Int., 83(1):45-8, 2008.

Kleinert, H.; Pulvertaft, R. \& Smith, D. Flexor Tendon Grafting in the Hand. Flynn's Hand Surgery. Baltimore,Williams \& Wilkins, 1991. pp. 285.
Köse, O.; Adanır, O.; Cirpar, M.; Kürklü, M. \& Kömürcü, M. The prevalence of absence of the palmaris longus: a study in Turkish population. Arch. Orthop. Trauma Surg., 129(5):609-11, 2009.

Köse, Ö.; Adanır, O.; Oto, M.; Kürklü, M. \& Kömürcü, M. The contribution of the palmaris longus muscle to the grip strength. Hand Microsurg., 1(1):7-9, 2012.

Machado, A. B. M. \& Di Dio, L. J. A. Frequency of the musculus palmaris longus studied in vivo in some Amazon Indians. Am. J. Phys. Anthropol., 27(1):11-9, 1967.

Mbaka, G. O. \& Ejiwunmi, A. B. Prevalence of palmaris longus absence-a study in the Yoruba population. Ulster Med. J., 78(2):90-3, 2009.

Mishra, S. Alternative tests in demonstrating the presence of palmaris longus. Indian J. Plast. Surg., 34(2):12-4, 2001.

Raouf, H. A.; Kader, G. A.; Jaradat, A.; Dharap, A.; Fadel, R. \& Salem, A. H. Frequency of palmaris longus absence and its association with other anatomical variations in the Egyptian population. Clin. Anat., 26(5):5727, 2013.

Sankar, K. D.; Bhanu, P. S. \& John, S. P. Incidence of agenesis of palmaris longus in the Andhra population of India. Indian J. Plast. Surg., 44(1):134-8, 2011

Sater, M. S.; Dharap, A. S. \& Abu-Hijleh, M. F. The prevalence of absence of the palmaris longus muscle in the Bahraini population. Clin. Anat., 23(8):956-61, 2010.

Schaeffer, J. P. On the variations of the palmaris longus muscle. Anat. Rec., 3(4):275-278, 1909.

Sebastin, S. J.; Lim, A. Y.; Bee, W. H.; Wong, T. C. \& Methil, B. V. Does the absence of the palmaris longus affect grip and pinch strength? $J$. Hand Surg. Br., 30(4):406-8, 2005a.

Sebastin, S. J.; Puhaindran, M. E.; Lim, A. Y.; Lim, I. J. \& Bee, W. H. The prevalence of absence of the palmaris longus--a study in a Chinese population and a review of the literature. J. Hand Surg., Br., 30(5):525$7,2005 b$.

Sharma, D. K.; Shukla, C. K. \& Sharma, V. Clinical assessment of absence of palmaris longus muscle and its association with gender, body sides, handedness and other neighboring anomalies in a population of Central India. J. Anat. Soc. India, 61(1):13-20, 2012.

Standring, S. Gray's Anatomy. The Anatomical Basis Of Clinical Practice. $39^{\text {th }}$ ed. Edinburgh, Elsevier Churchill Livingstone, 2005. pp.458.

Thompson, J. W.; McBatts, J. \& Danforth, C. H. Hereditary and racial variation in the musculus palmaris longus. Am. J. Phys. Anthropol., $4(2): 205-18,1921$.

\section{Corresponding author: \\ Keziban Karakan \\ Assistant Professor, Ph.D. \\ Department of Anatomy \\ Faculty of Medicine \\ University of Sakarya \\ The neighborhood of Korucuk \\ The campus of Korucuk \\ Adapazari, Sakarya \\ TURKEY}

\section{E-mail:kkaracan@sakarya.edu.tr}

Received:10-11-2016

Accepted:10-04-2017 